\title{
Perkembangan Musik Gereja dan Interpretasi Pemusik Gereja Terhadap Nyanyian Jemaat Di Gereja Sinta Kuala Kapuas
}

\author{
Berth Penny Pahan \\ Institut Agama Kristen Negeri Palangka Raya \\ berthpenny@yahoo.co.id
}

\begin{abstract}
Church music is part of worship service in a church. Each church denomination has church musik management according its tradition and habitual. Sinta Church in Kuala Kapuas as an old church is hoped as a barometer locally or regionally of Kalimantan Evangelical Church in singing congregation song. In its development so far church music at Sinta Church has been arranged in such a way for improving the quality and quantity in singing congregation songs. In this research, the researcher tried to conduct the problem dan development of church musik in Sinta Church Kuala Kapuas. The goal was to find out a general about church music management so it would be found the solutions constructively in improvinf the quality and quantity in singing congregation songs. By using descriptive qualitative method, it would be presented the research data from depth interview. The conclusion of this research that church music management in Sinta Church has been developed in such a way just like practicing and scheduling in Sunday news and also has been held by musicions and song leaders.
\end{abstract}

Keywords: church music; congregation assembly; development; interpretation

\begin{abstract}
Abstrak
Musik gereja adalah bagian dari ibadah atau pelayanan di gereja. Setiap denominasi gereja mempunyai penataan musik gereja masing-masing sesuai dengan tradisi atau kebiasaan gereja tersebut. Gereja Sinta di Kuala Kapuas sebagai salah satu gereja yang cukup tua dari segi usia diharapkan menjadi barometer di tingkat lokal atau bahkan di tingkat regional Gereja Kalimantan Evangelis (GKE) dalam hal menyanyikan nyanyian jemaat. Selama ini dalam perkembangannya musik gereja di Gereja Sinta telah diatur sedemikian rupa untuk meningkatkan kualitas bernyanyi dan kuantitas nyanyian jemaat yang dinyanyikan. Dalam penelitian ini penulis mencoba mengangkat permasalahan dan perkembangan musik gereja di Gereja Sinta Kuala Kapuas. Tujuannya untuk mendapatkan suatu gambaran umum sehingga nantinya diharapkan akan dilakukan solusi-solusi yang bersifat konstruktif untuk peningkatan kualitas dan kuantitas bernyanyi nyanyian jemaat. Dengan metode penelitian deskriptif kualitatif akan dipaparkan data penelitian dari hasil wawancara mendalam. Kesimpulan dari penelitian ini musik gereja di Gereja Sinta Kuala Kapuas telah berkembang cukup baik secara penataan dan diatur sedemikian rupa dalam bentuk latihan dan penjadwalan pada berita jemaat Minggu dan dilaksanakan oleh organis serta pemandu lagu.
\end{abstract}

Kata Kunci: interpretasi; musik gereja, perangkat musik gereja, majelis jemaat

\section{Pendahuluan}

Musik gereja merupakan bagian integral dari suatu tata ibadah di gereja manapun. Musik gereja baik dengan instrumen musik maupun tanpa instrumen adalah musik gereja itu sendiri dengan segala permasalahannya. Kemampuan menginterpretasi suatu 
nyanyian jemaat masih sangat kurang yang dilakukan oleh perangkat musik gereja, baik itu dari segi birama, tempo, ketepatan nada, artikulasi, dan lain-lain. Perangkat musik gereja seperti pemain musik, pemandu lagu, praktisi musik gereja dan gereja itu sendiri sebagai ujung tombak perkembangan musik gereja belum mampu memberikan sajian musik yang seharusnya menurut keinginan nyanyian itu sendiri. Masih banyak nyanyian yang dinyanyikan secara keliru tapi bukan salah karena lebih menganggap kebiasaanlah yang dianggap benar dalam bernyanyi. Partitur lagu adalah alat baca bait lagu saja bukan notasinya yang penting untuk dinyanyikan secara benar.

Pada dasarnya dalam tata ibadah Gereja Kalimantan Evangelis (GKE) di gereja dalam setiap kebaktian minggu dan hari raya gereja terdapat enam sampai delapan nyanyian yang dinyanyikan bersama.Tentu saja nyanyian tersebut akan menjadi alat pembaharu secara langsung yang dirasakan oleh jemaat karena bagian bernyanyi tentu melibatkan jemaat sebagai subyek bernyanyi terlebih kalau kita nyanyikan secara musikal teoritis baik dan benar. Kemampuan organis dan pemandu lagu memandu jemaat dalam bernyanyi memang masih jauh dari keinginan nyanyian itu sendiri oleh karena itu mereka harus lebih diperkaya dalam hal teori musik, diskusi dengan pakar musik, seminar, loka karya dan latihan rutin. Penguasaan lagu yang meyakinkan jemaat sangat penting dilakukan oleh organis dan pemandu lagu terlebih untuk lagu-lagu baru sehingga lagu-lagu itu tetap dinyanyikan bersama bukan diserahkan kepada pemandu lagu sehingga jemaat menjadi pasif.

Menurut Soumokil (2001) sebagaimana Kristus yang adalah kepala, dari padaNyalah seluruh tubuh yang rapi tersusun dan diikat menjadi satu demikianlah gereja juga mempunyai organisasi yang baik, aturan-aturan, tatanan, pemahaman ajaran-ajaran gereja yang terarah maka musik pun tidak terlepas dari aturan dan tatanan yang rapi dan teratur. Dari pernyataan ini kita tentu ingin tatanan dan sajian musik gereja akan lebih baik menurut keinginan nyanyian dan teori musik itu sendiri dan pemain organ serta pemandu lagu akan mampu berkolaborasi dengan jemaat dalam bernyanyi. Musik akan menjadi alat respons yang dapat membuat umat menghayati arti pertemuan dengan Tuhan, musik akan menyemangati atau menjadi garam dalam pertemuan umat dengan Tuhan.

Untuk itulah penelitian ini akan menjadi perintis dalam memberikan referensi dalam penyajian musik gereja. Melalui penelitian ini penulis ingin mengetahui perkembangan musik gereja dan interpretasi pemusik gereja terhadap Nyanyian Jemaat di GKE Sinta Kuala Kapuas. Dari penelitian ini diharapkan akan terangkat berbagai hal yang telah dilakukan dalam pembinaan musik gereja dan masalah-masalah apa yang dialami dalam bernyanyi baik itu yang dirasakan oleh pemain organ, pemandu lagu maupun oleh jemaat, sehingga akan terdapat suatu acuan dalam mengatasi permasalahan yang dihadapi dan menjadi bahan masukan kepada GKE. Pada akhirnya penelitian ini diharapkan akan menjadi generalisasi bagi semua majelis jemaat di lingkungan Gereja Kalimantan Evangelis dalam melihat permasalahan bernyanyi nyanyian jemaat.

Adapun tujuan penelitian ini adalah: 1) Untuk memberikan gambaran umum tentang perkembangan musik gereja di Gereja Sinta, Majelis Jemaat GKE Selat Kuala 
Kapuas; 2) Untuk mengetahui kendala-kendala yang dihadapi oleh pemain organ dalam menyajikan musik gereja yang sebenarnya; 3) Untuk mengetahui kendala-kendala yang dihadapi pemandu lagu dalam menyajikan nyanyian jemaat yang sebenarnya; 4) Untuk mengetahui kebiasaan bernyanyi jemaat dalam menyanyikan nyanyian jemaat.

\section{Metode}

Penelitian ini termasuk jenis penelitian deskriptif kualitatif yang berupaya menjelaskan kondisi riil cara bernyanyi nyanyian jemaat atau musik gereja itu sendiri pada saat ini di Majelis Jemaat GKE Selat Kuala Kapuas dengan fokus penelitian pada gereja Sinta pada ibadah minggu dan hari raya gereja. Pengumpulan data melalui obervasi dan wawancara. Instrument yang digunakan adalah kuesioner terbuka dan/atau pedoman wawancara yang tidak terstruktur atau ada juga yang hanya menggunakan catatan khusus dan alat rekaman suara dan peristiwa (Muhammad dan Djaali, 2005). Dalam penelitian kualitatif, pengumpulan data dan analisa berjalan seiring untuk mengembangkan suatu teori yang substantif berdasarkan data empirik (Muhammad dan Djaali, 2005). Dari pendapat di atas peneliti akan menganalisis data secara kualitatif dengan perolehan data sebanyak-banyaknya dari berbagai nara sumber yang berkaitan dengan musik gereja.

\section{Hasil dan Pembahasan}

\section{Musik secara Umum}

Sepanjang sejarah umat manusia musik telah terbukti mempunyai peranan dalam mengekspresikan kehidupan umat manusia itu sendiri dari seala aspek kehidupan yang sesuai dengan berbagai latar belakang budaya di dunia ini. Ada musik untuk perang, ada musik untuk panen, ada musik untuk upacara-upacara tertentu seperti perkumpulan adat, syukuran, hiburan, dll. Alkitab pun cukup memberi gambaran tentang peranan musik dalam kehidupan umat manusia sebagai ungkapan syukur atas kebesaran Allah (Soumokil, 2001). Dengan demikian musik akan sangat berperan dalam pelayanan kebaktian di gereja, musik akan bersinerji dengan perangkat ibadah yang lain seperti pendeta, penatua diakon, jemaat, pemandu lagu, dan pemain organ.

Musik adalah cabang seni yang membahas dan menetapkan berbagai suara kedalam pola-pola yang dapat dimengerti dan dipahami manusia (Banoe, 2003). Menurut Jamalus (1988) musik adalah suatu hasil karya seni bunyi dalam bentuk lagu atau komposisi musik, yang mengungkapkan pikiran dan perasaan penciptanya melalui unsur-unsur musik, yaitu irama, melodi, harmoni, bentuk/struktur lagu dan ekspresi sebagai satu kesatuan. Senada dengan Jamalus, menurut Soeharto (1992) seni musik adalah "pengungkapan gagasan melalui bunyi yang unsur dasarnya berupa melodi, irama, dan harmoni dengan unsur pendukung berupa bentuk, sifat, dan warna bunyi".

\section{Musik Gereja}

Pengertian musik yang dimaksudkan di sini adalah pengertian musik yang dihubungkan dengan istilah gerejawi, sehingga menjadi musik gerejawi. Untuk 
memberikan batasan istilah musik gerejawi, maka terlebih dahulu harus memiliki pengertian yang jelas tentang kedua istilah tersebut (musik dan gerejawi). Pengertian musik sudah dielaborasikan pada bagian di atas, dan berikut ini akan dipaparkan pengertian tentang istilah gerejawi. Kata gerejawi adalah bentuk ajektiva dari kata gereja. Artinya adalah berkenaan dengan gereja. Kata gereja bisa menunjuk kepada gedung gereja, dan bisa juga menunjuk kepada semua organisasi gereja sebagai wadah persekutuan orang Kristen yang memiliki denominasi masing-masing. Tetapi penulis ingin mengaksentuasikan makna gereja yang paling hakiki, yaitu bukan menunjuk kepada gedung gereja atau denominasi gereja tertentu, melainkan menunjuk kepada persekutuan orang-orang percaya, orang-orang yang telah dipanggil Tuhan menjadi umat-Nya. Dalam pengertian inilah, penulis menggunakan istilah gereja dalam batasan musik gerejawi yang akan dikemukakan berikut ini.

Berdasarkan pengertian gereja tersebut di atas, maka musik gerejawi dapat didefinisikan sebagai berikut: 1) Sebagai ilmu, musik gerejawi adalah pengetahuan tentang hal menggabungkan nada-nada, yang berbentuk bunyi vokal (suara manusia) atau bunyi instrumental, dalam berbagai macam irama, melodi/lagu dan harmoni untuk menghasilkan komposisi yang mampu mengungkapkan pikiran dan emosi manusia (sebagai orang percaya) dalam hubungannya dengan Tuhan yang dipercayainya; 2) Sebagai hasil karya seni, musik gerejawi adalah nada yang berbentuk bunyi vokal (suara manusia) atau bunyi instrumental, yang disusun sedemikian rupa sehingga menghasilkan komposisi suara/bunyi yang mengandung irama, melodi/lagu dan harmoni yang merupakan kesatuan yang utuh dan berkesinambungan, yang mengekspresikan pikiran dan emosi komposer (sebagai orang percaya) yang dapat mempengaruhi pikiran dan emosi orang lain yang mendengarkan atau memainkan/menyanyikan hasil komposisi tersebut dan mengakibatkan perubahan sikap dan perilaku orang tersebut yang memuliakan Tuhan, dan musik gerejawi ini digubah untuk meresponi karya penyelamatan Tuhan di dalam Kristus untuk orang berdosa.

Di dalam kedua definisi ini (musik gerejawi sebagai ilmu dan hasil karya seni), dapat dilihat adanya dua unsur fundamental yang menjadi bahan substansial dalam membuat musik gerejawi, yaitu bunyi vokal dan bunyi instrumental. Bunyi vokal yang dimaksudkan di sini adalah bunyi yang dihasilkan dengan menggunakan mulut manusia, dan bunyi itu disebut suara. Sedangkan bunyi instrumental adalah bunyi yang dihasilkan dengan menggunakan alat musik. Jadi, musik gerejawi itu bukan hanya berbentuk musik instrumental, tetapi juga berbentuk musik vokal atau lagu/puji-pujian (musik yang diberi syair/lirik). Dengan demikian, jelaslah bahwa musik gerejawi itu bukan hanya bersangkut paut dengan para pemain musik saja, tetapi juga bersangkut paut dengan seluruh jemaat Tuhan sebagai "vokalis" (Pahan, 2020).

Musik dalam gereja bukan sekedar seni musik pada umumnya. Musik dalam gereja mempunyai fungsi dan peranan yang jauh dari sekedar sebagai seni. Musik gereja adalah suatu aspek dari pengakuan iman dan kesaksian umat. Ukur (2001) menjelaskan nyanyian gereja itu tetap mempunyai ciri khasnya sendiri, ia merupakan ekspresi/ungkapan persekutuan rohani yang mampu mempersekutukan semua anggota 
gereja, besar kecil, tua muda, laki perempuan. Ia juga sekaligus merupakan pernyataan iman jemaat, memuat pengajaran dan pengharapan umat. Kita dapat melihat betapa dahsyatnya peranan musik gereja apabila ditelaah secara teologis, jadi musik gereja bukan hanya hiasan berupa nyanyian selama ibadah tetapi ia adalah alat ekspresi umat sebagai subyek ciptaan Tuhan.

Abineno (1986) menyatakan bahwa 1) Nyanyian Gerejawi adalah jawaban-ucapan syukur atau puji-pujian-jemaat atas karya-karya Allah dalam Yesus Kristus. Nyanyian Gerejawi adalah salah satu unsur yang paling penting dalam hidup jemaat. 2) Nyanyian gerejawi bukan saja jawaban jemaat atas perbuatan-perbuatan Allah yang besar, tetapi ia juga adalah pemberitaan tentang perbuatan-perbuatan itu. Secara sadar kita akan berkata bahwa musik gereja adalah bersifat Aklamasi dan Proklamasi. Dengan aklamasi kita mengaku diri kepada Allah, dengan proklamasi kita memaklumkan KerajaanNya kepada dunia. Aklamasi tidak hanya terungkap melalui musik, tetapi juga dalam doa, mengikuti pelayanan firman, sakramen dan kehidupan kita sehari-hari, begitu juga memprolamasikan kerajaan Allah kepada dunia tidak hanya melalui nyanyian, tetapi juga dengan mulut, tangan dan tindakan sehari-hari. Nyanyian kita mengiringi semuanya itu sebagai ekspresi hati yang menerangkan kesungguhan kita dalam Aklamasi kepada Allah maupun Proklamasi kepada dunia. Selain sebagai Aklamasi dan Proklamasi musik gereja juga berfungsi untuk saling mendidik, mengajak dan menguatkan.

\section{Penataan Musik Gereja}

Ibadah bukan sekedar pertemuan anggota jemaat dalam suasana yang menyenangkan namun perlu mampu membawa jemaat dapat merasakan dan menghayati pengalaman imannya dalam berjumpa dengan Tuhan. Ibadah harus bisa dihayati dan menyentuh kebutuhan spiritual jemaat. Suasana musik ibadah gereja berbeda dengan penyajian musik di amusement centre atau diskotik. Ibadah bukan bertujuan untuk menyenangkan atau memuaskan perasaan jemaat, sebab ibadah bukan entertainment rohani. Ibadah dimaksudkan untuk membentuk atau mendukung pertumbuhan hidup spiritual jemaat. Gereja secara sengaja dan serius perlu mengupayakan pembentukan atau pertumbuhan hidup spiritual jemaat melalui ibadatnya (liturgi). Karena itu diperlukan rekrutmen dan pembinaan pemusik dengan cara yang tepat untuk menangani musik instrumen maupun vokal dalam ibadah.

Dalam Alkitab pun musik sudah dilembagakan dan ditata dengan baik, musik pada saatitu mendapat perhatian dan penanganan serta kepeimpinan yang baik dan terarah. Raja Daud malah mengkhususkan bani Lewi sebagai penyanyi-penyanyi yang terampil di bawah asuhan Asaf, Heman dan Yedutum (Soumokil, 2001). Jadi apa salahnya kita menata musik gereja dengan sebaik-baiknya, sehingga penyajian musik gereja setiap minggunya akan terasa lebih mantap dan memuaskan umat dalam bernyanyi memuji Tuhan.

\section{Perangkat Musik Gereja}

Dua kata asing yang sering digunakan dalam menunjuk pemimpin nyanyian ibadah adalah Cantoria dan Prokantor. Istilah ini berasal dari sejarah liturgi yang digunakan 
untuk para penyanyi ibadah serta pemimpinnya. Dalam Perjanjian Lama disebutkan suku Lewi (astinya rohaniawan) yang ditunjuk untuk berfungsi sebagai penyanyi-penyanyi ibadah dibawah pemimpin yang terkenal seperti: Asaf, Heman, Yedutun, dan seterusnya. Raja Daud melembagakan pelayanan musik ibadah Israel (lihat 1 Tawarikh 25:1-8, Nehemia 12:46). Maka sepanjang sejarah Israel dan gereja dapat dijumpai penampilan kelompok penyanyi dan pemimpinnya.

Istilah Cantor atau Prokantor seperti halnya istilah pastor (untuk gembala atau pendeta yang tinggal di pastori), koster (berarti penjaga tempat suci di kosteri) dan lektor (kata Latinnya Lector berarti pembaca khususnya pembaca Alkitab). Secara historis fungsi prokantor, lektor, koster tergolong pada ordines minores atau "jabatan-jabatan lebih kecil", lain daripada ordines majores atau "jabatan yang lebih besar" seperti presbyter atau penatua, diaken).

Dalam tradisi gereja (khususnya gereja katholik yang melatarbelakangi gerejagereja Protestan) fungis Prokantor dan Kantoria itu tetap bersifat jabatan atau pelayanan rohani resmi yang memerlukan ordinasi (pengangkatan dan peneguhan gerejawi lengkap dengan segala persyaratan dan janji janjinya). Dalam tradisi Israel, penyanyi dan pemimpin nyanyian disebut Menatseakh (pengangkat nyanyian, pemimpin biduan), dalam tradisi sinagoge Yahudi disebut Khazzan, dalam gradisi gereja Yunani disebut Psaltes, dalam tradisi gereja Barat Cantor (Bahasa Latin) atau Cantore (Itali), Chantre (Bahasa Perancis), Kantor (Jerman) dan Precenter (Inggris). Precenter berasal dari bentuk bahasa Latin Procantor yaitu pemimpin biduan suara pertama yang memulai nyanyian Antifonal, disamping Subcantor yang memimpin paduan suara kedua yang menjawab dalam nyanyian berbalasan. Oleh karena itu Prokantor dapat diartikan dengan 'yang menyanyi lebih dulu" (Voor-zanger: bahasa Belanda). Untuk orang Indonesia istilah Prokantor lebih tepat untuk membedakan dengan Cantor (baca kantor) untuk membedakan dengan kantor pos, kantor polisi dst.

Prokantor yang paling terkenal dalam sejarah musik gereja adalah Johann Sebastian Bach (abad 18). Ia bertugas sebagai ko-ordinator, perancang, pemimpin, penanggungjawab musik ibadah di Gereja Thomas-Leipzig. Di Amerika Serikat tidak digunakan istlah prokantor, tetapi seorang pelayan musik disebut "Minister of Music", yang fungsinya dalam ibadah cukup penting disamping Minister of Word (Pelayan Firman biasanya disebut Pendeta). Pendidikan yang dibutuhkan dan statusnya dalam jemaat sama dengan pendeta lainnya.

Secara historis fungsi Pimpinan Nyanyian Ibadah adalah suatu fungsi (jabatan atau pelayanan) yang penting. Selama belum mempunyai ahli ahli dalam bidang formal tersebut, maka dirigen PS dan orang-orang terbaik dalam PS dan musik perlu mendukung tugas tersebut. Bersama dengan paduan suara, membentuk kantoria memulai mengangkat atau menyanyi dalam ibadah gereja.

Unsur musik gereja yang paling pokok dalam ibadah adalah prokantor (pemimpin pemandu lagu), kantoria (pemandu lagu), permainan instrumental (pemain musik), nyanyian solo, vokal group, paduan suara dan nyanyian jemaat. Dengan demikian maka semua perangkat musik gereja harus mendapat perhatian dan pembinaan yang baik. 
Paduan suara baru dapat berfungsi optimal jika mampu menghias, menyemangati nyanyian jemaat dengan berbagai cara. Demikian juga fungsi vokal group atau ensemble musik apapun akan sangat bermanfaat jika dapat menjadi satu dalam nyanyian jemaat. Ini tidak berarti tidak ada tempat bagi paduan suara, vocal group untuk nyanyian lepas dalam ibadah. Tempatnya tetap ada asal lagu yang dinyanyikan tidak lepas dari konteks ibadah serta disadari bahwa fungsi para penyanyi dan musisi belum lengkap jika belum melibatkan diri dalam nyanyian jemaat. Perlu ada interaksi antara semua unsur dalam menunjang nyanyian jemaat.

Gedung Gereja Sinta Kuala Kapuas berlokasi di Jalan Ahmad Yani/Seth Adji yang merupakan jalan protokol didirikan pada tahun 1950-an dan gereja GKE pertama yang didirikan di Kuala Kapuas. Gereja Sinta ini sebelum mencapai bentuknya yang sekarang sudah mengalami beberapa kali pemugaran. Bangunan awal terbuat dari bahan kayukayu pilihan dan mampu menampung lima ratus sampai tujuh ratus jemaat, karena perkembangan jaman dan untuk menyesuaikan dengan perkembangan kota maka pada tahuan 1997 direncanakan pembangunan dengan rangka besi beton dan perluasan daya tampung gereja dan rehabilitasi gereja Sinta berjalan cukup lama dan telah mencapai bentuknya yang sekarang dengan daya tampung sekitar seribu jemaat. Fasilitas sudah memadai untuk pelaksanaan acara-acara gereja di samping kebaktian Minggu. Fasilitas yang tersedia adalah altar dan mimbar pelayanan, kursi jemaat, penerangan yang memadai dengan penambahan lampu-lampu hias, sound system sekitar 1000 watt, seperangkat alat band, laptop, LCD + layar, areal parkir yang cukup luas.

Akustik diartikan sebagai sesuatu yang terkait dengan bunyi atau suara, sebagaimana pendapat Shadily (1987) bahwa akustik berasal dari kata dalam bahasa Inggris: acoustics, yang berarti ilmu suara atau ilmu bunyi. Halme (1990) menyebutkan: Acoustics is a science and the first consideration to get a comfortable sound environment, bahwa akustik merupakan suatu ilmu dan merupakan pertimbangan pertama untuk mendapatkan lingkungan suara yang nyaman, sebagaimana pendapatnya: Jadi Tata Akustik merupakan pengolahan tata suara pada suatu ruang untuk menghasilkan kualitas suara yang nyaman untuk dinikmati, merupakan unsur penunjang terhadap keberhasilan desain yang baik karena pengaruhnya sangat luas dan dapat menimbulkan efek-efek fisik dan emosional dalam ruang sehingga seseorang akan mampu merasakan kesan-kesan tertentu (Ambarwati, 2009).

Masalah utama dari bangunan gereja Sinta ini adalah interior dan atap bangunan yang terlalu tinggi sehingga berpengaruh kepada kenyamanan pendengaran terhadap pantulan suara yang terlalu sering. Ini terjadi karena pembuatan plafon dilakukan dengan sistim tertutup habis artinya tidak ada sekat-sekat pembuang suara yang mengurangi pantulan. Apabila pendeta berkhotbah atau ada pidato bisa terjadi suara yang keluar kurang jelas karena akibat pantulan suara yang terlalu banyak (over-reverb). Masalah ini cukup teratasi dengan menempatkan loudspeaker di bagian bawah sejajar dengan posisi duduk jemaat walaupun pantulan suara masih terasa tetapi tidak terlalu banyak lagi. Hubungannya dengan penyajian musik gereja adalah apabila suara yang diproduksi 
cukup bagus maka pemanduan dalam bernyanyi akan berjalan maksimal dan diharapkan tata suara yang diatur baik akan memaksimalkan penyampaian nyanyian kepada jemaat.

\section{Hasil Observasi Kebaktian Minggu di Gereja Sinta}

Penulis mengadakan observasi pada kebaktian Minggu untuk mendapatkan gambaran umum tentang penyajian musik gereja selama kebaktian. Pada hari Minggu dilaksanakan tiga kali kebaktian yaitu : Sinta I (Pukul 06.30 WIB), Sinta II (Pukul 09.00 WIB), Sinta III (Pukul 16.00 WIB). Pada kebaktian Sinta I dan II menggunakan iringan organ dan pemandu lagu untuk memandu jemaat dalam bernyanyi dan nyanyian yang dipakai masih dominant Nyanyian Kidung Jemaat dan ada pendeta yang mulai mensosialisaikan Nyanyian Pelengkap Kidung Jemaat. Pada kebaktian Sinta I dan II musik gereja dipandu oleh organis dan pemandu lagu yang ditugaskan pada jam tersebut. Dari segi penyajian penulis mengamati adanya suatu usaha untuk menyajikan musik gereja sebaik mungkin dengan segala daya dan upaya serta keterbatasan teori dan praktik adanya hal-hal yang kurang mengena secara teori dari setiap akor-akor yang dimainkan serta nyanyian jemaat yang dinyanyikan. Fasilitas pendukung kebaktian terdapat: Laptop + LCD untuk menampilkan liturgy dan partitur nyanyian jemaat yang dinyanyikan ini adalah suatu perkembangan dalam penggunaan teknologi computer untuk member kemudahan dalam kebaktian dan menjadi daya tarik tersendiri bagi warga jemaat.

Hasil pengamatan dari sisi Organis adanya perkembangan dan masalah yaitu: 1) Organis memainkan nyanyian jemaat berdasarkan kebiasaan, baik dari segi tempo, birama dan irama, akor, lagu, intro. Pada tempo intro lebih cepat dan berkurang pada saat pemandu lagu dan jemaat bernyanyi artinya tempo tidak stabil. Pada birama ada pengurangan ketukan pada beberapa akhir frase lagu. Pada irama belum adanya penyesuaian irama dengan karakter lagu, misalnya dengan irama march pada lagu Maju Laskar Kristus permainan bass pada jari tangan kiri belum semestinya dimainkan dengan baik untuk membangkitkan mood bernyanyi jemaat. Atau lagu dengan irama waltz organis belum bisa memberi nuansa waltz misalnya pada nyanyian KJ. 400 Kudaki Jalan Mulia bisa diberikan sentuhan waltz yang kental agar ada ketegasan pada birama dan irama. Belum jelas permainan notasi marcato dan legato. Untuk nada dasar nyanyian jemaat cenderung tetap dimainkan sesuai partitur. Organis memainkan nyanyian jemaat dengan tempo lambat pada beberapa lagu karena menyesuaikan dengan kebiasaan bernyanyi jemaat. Cara bermain yang masih mengunakan akor pada tangan kiri membuat permainan hanya berupa perpindahan akor semata tanpa kombinasi bass inversion dan lompatan nada yang mengantar pada kombinasi nada berikutnya. Lebih berdasarkan 'feeling' daripada partitur sehingga ada akor-akor yang terlewatkan. Untuk pemilihan tone masih dominan menggunakan tone organ belum ada yang mengkombinasikan dengan string untuk lagu-lagu yang riang. Untuk nyanyian yang jarang atau baru dinyanyikan terdapat kesalahan bermain.

Hasil Pengamatan dari sisi Pemandu Lagu ada perkembangan dan masalah. Pemandu lagu berusaha menyanyikan nyanyian jemaat sebaik-baiknya dengan memperhatikan tempo jemaat dan organis, tetapi ada juga kecenderungan untuk 
menyanyi dengan tempo sendiri. Usaha untuk mempertahankan tempo yang ada pada intro lagu dari organis tetap dilakukan sehingga mulai ada kestabilan tempo. Lagu pada setiap nyanyian jemaat berusaha dinyanyikan sesuai partitur secara keseluruhan artinya notasi marcato dan legato mulai jelas. Kadang-kadang ada melakukan kesalahan bernyanyi pada beberapa nyanyian yang dianggap jarang atau bahkan baru dinyanyikan karena latihan hanya dilakukan sebelum kebaktian.

Pada kebaktian Sinta III musik gereja dipandu oleh kelompok band dan pemandu lagu, dalam penyajiannya penulis mengamati adanya beberapa perkembangan dan juga masalah. Hasil Pengamatan dari sisi Kelompok Band dan Pemandu Lagu ada perkembangan dan masalah yaitu: 1) Gereja Sinta baru memberdayakan kelompok band untuk mengiring jemaat mulai tahun 2008 khusus kebaktian Sinta III, ini adalah suatu perkembangan yang signifikan; 2) Peralatan band yang digunakan cukup representatif dengan kualitas bunyi yang layak dengar; 3) Berani menyajikan musik gereja menggunakan band untuk ukuran GKE adalah suatu terobosan karena ada anggapan penggunaan band untuk kebaktian hanya didominasi oleh denominasi gereja tertentu; 4) Bermain band dengan penyajian musik gereja tentu menghadapi berbagai kendala dan ini dianggap sebagai proses pematangan untuk mencapai performa yang maksimal atau punya 'greget'; 5) Masalah utama yang bersifat teknis penyajian adalah penguasaan dan pembawaan nyanyian jemaat itu sendiri; 6) Permainan akor yang berbeda antar personil gitar, bass dan kibod pada beberapa nyanyian membuat penyajian menjadi tidak utuh sehingga menghasilkan bunyi yang tidak harmonis; 7) Untuk tempo, irama dan birama ditentukan oleh permainan drum. Terkadang penguasaan birama yang belum mapan membuat nyanyian dengan birama $3 / 4$ bisa bias menjadi $4 / 4$ atau sebaliknya, juga 6/8 bisa bias menjadi 3/4 atau sebaliknya; 8) Untuk latihan sudah diatur pada hari Sabtu semua personil diharapkan hadir, karena daftar lagu untuk kebaktian sudah ada di berita jemaat, sehingga penyajian diharapkan lebih maksimal; 9) Untuk pemandu lagu berusaha melakukan penyesuaian dengan kelompok band terutama untuk attack maupun antar bait nyanyian, sehingga kelompok band mengiring pemandu lagu maksudnya kalau nyanyian sudah berjalan ada situasi-situasi yang sifatnya toleransi untuk saling menyesuaikan dan meminimalkan kesalahan; 10) Adanya keragu-raguan dalam bernyanyi dan mengiring untuk nyanyian jemaat yang jarang atau baru dinyanyikan.

Hasil Pengamatan dari sisi Jemaat. Dari sisi jemaat dapat dikatakan adanya sifat antusias dalam bernyanyi memuji Tuhan pada setiap jam kebaktian di gereja Sinta. Dengan adanya perangkat musik gereja yang ditata dan bekerja sesuai porsinya maka gairah bernyanyi terasa kental sekali, hal ini bermakna positif untuk keseimbangan dalam kebaktian dimana partisipasi jemaat merespon pertemuannya dengan Tuhan Allah secara pribadi dalam bentuk bernyanyi memuji Tuhan adalah kesempatan setiap pribadi untuk mengaklamasikan dan memproklamasikan kerajaan Allah di dunia ini.

Pada dasarnya jemaat yang berkebaktian di gereja Sinta untuk semua sesion adalah jemaat yang pandai bernyanyi, responsif dan sangat mengapresiasi setiap nyanyian jemaat yang telah diatur. Tanpa mengenyampingkan masing-masing talenta bernyanyi 
yang berbeda-beda keadaan jemaat di gereja Sinta pada saat kebaktian semuanya pro aktif untuk memuji Tuhan.

\section{Analisa Hasil Observasi dan Wawancara}

Dalam menyelenggarakan musik gereja yang baik dalam ibadah, tentu diperlukan adanya kepemimpinan yang baik. Hal ini tentu tidak dapat dipisahkan dari faktor manusia sebagai sumber daya serta penunjang lainnya seperti pengetahuan dan sarana yang memadai yang ditunjang dengan pemahaman serta dedikasi yang cukup. Di samping sumber daya manusia yang berkompetensi tentu juga harus didukung oleh prasarana dan sarana yang berkualitas. Ketiga sumber daya tersebut yang diharapkan berkualitas dan layak diandalkan untuk pelaksanaan musik gereja akan menentukan kualitas pelayanan musik gereja itu sendiri.

Dari hasil observasi dan wawancara di atas dapat dianalisa bahwa musik gereja di Gereja Sinta Kuala Kapuas mengalami perkembangan dan problematika. Perkembangan dan permasalahan tersebut terjadi baik pada saat persiapan maupun pada saat penyajiannya. Berikut Analisa musik gereja di Gereja Sinta Kuala Kapuas: 1) Berkembang dengan baik dan terdapat kemajuan yang pesat dalam bernyanyi memuji Tuhan untuk lingkup jemaat walaupun kadang-kadang menghadapi kendala-kendala seperti sumberdaya praktisi musik dan menyanyi yang sangat terbatas sehingga orangnya selalu itu-itu saja. Untuk fasilitas peralatan musik (seperangkat alat band) dan soundsystem sudah memadai, ada juga Laptop + LCD untuk menunjang pelaksanaan kebaktian. Untuk kebaktian Sinta I dan II tetap menggunakan iringan organ dan pemandu lagu. Pemberdayaan kelompok band untuk mengiring kebaktian untuk Sinta III; 2) Membuat penjadwalan pemain organ; 3) Menyediakan peralatan musik (band) + soundsystem yang memadai; 4) Menyediakan laptop + LCD selama kebaktian untuk penayangan liturgi dan partitur nyanyian; 5) Membuat pertemuan dengan pendeta untuk menanyakan dan mengkonsultasikan nyanyian apa yang akan dinyanyikan pada saat kebaktian Minggu; 6) Memberdayakan penetua dan diakon yang bertugas dalam meningkatkan kemampuan bernyanyi; 7) Pembentukan kelompok paduan suara d lingkungan pelayanan untuk ditampilkan pada saat bertugas d samping itu terdapat juga kelompok paduan suara dengan nama-nama tertentu seperti Paduan Suara Sinta, Paduan Suara yang dipimpin Bapak G. G. Pahan, Bapak Ragus Rumbang; 8) Memberikan insentif kepada perangkat musik gereja; 9) Ada yang pernah mengikuti seminar musik dan lokakarya musik ada juga yang belum; 10) Mengadakan latihan rutin untuk kelompok band pada hari Sabtu dan pertemuan dengan pendeta untuk persiapan nyanyian pada kebaktian Minggu; 11) Sudah dilakukan kaderisasi dengan memberi pengetahuan bernyanyi nyanyian jemaat pada katekesasi dan pemberdayaan penetua dan yang bertugas; 12) Sudah menyediakan fasilitas tersebut di atas; 13) Untuk nyanyian yang dipakai masih dominan menggunakan Kidung Jemaat dan ada usaha untuk menambah dari Pelengkap Kidung Jemaat; 14) Sudah sesuai karena Pendeta pelayanan melihat minggu apa yang tertera dalam Almanak Nast GKE; 15) Ada pemain organ yang bisa mengemas permainannya dengan baik artinya sesuai dengan rambu-rambu yang ada dalam partitur, tetapi ada juga yang masih belum 
menyajikan secara maksimal dari segi pengemasan nyanyian; 16) Sudah ada diskusi selama latihan atau setelah kebaktian untuk penyamaan persepsi tentang cara pembawaan nyanyian yang sebenarnya seperti apa; 17) Dilatih lebih dulu dengan lebih dulu bertemu dengan pendeta meminta petunjuk dan melatihnya bersama pemain organ atau band kemudian melatihnya sebelum kebaktian; 18) Gereja Sinta baru memberdayakan kelompok band untuk mengiring jemaat mulai tahun 2008 khusus kebaktian Sinta III, ini adalah suatu perkembangan yang signifikan; 19) Peralatan band yang digunakan cukup representatif dengan kualitas bunyi yang layak dengar; 20) Berani menyajikan musik gereja menggunakan band untuk ukuran GKE adalah suatu terobosan karena ada anggapan penggunaan band untuk kebaktian hanya didominasi oleh denominasi gereja tertentu.

\section{Implikasi}

Musik dalam gereja bukan sekedar seni musik pada umumnya. Musik dalam gereja mempunyai fungsi dan peranan yang jauh dari sekedar sebagai seni. Musik gereja adalah suatu aspek dari pengakuan iman dan kesaksian umat. Melalui musik gereja yang lebih menempatkan diri sebagai aspek pengakuan iman dan kesaksian umat diharapkan disajikan secara baik dan teratur sesuai dengan tata kelola pelayanan musik gereja.

Permasalahan pelaksanaan musik gereja di Gereja Sinta Kuala Kapuas mempunyai beberapa implikasi sebagai berikut: 1) Organis memainkan nyanyian jemaat berdasarkan kebiasaan, baik dari segi tempo, birama dan irama, akor, lagu, intro; 2) Pada tempo intro lebih cepat dan berkurang pada saat pemandu lagu dan jemaat bernyanyi artinya tempo tidak stabil; 3) Pada birama ada pengurangan ketukan pada beberapa akhir frase lagu; 4) Pada irama belum adanya penyesuaian irama dengan karakter lagu, misalnya dengan irama march pada lagu Maju Laskar Kristus permainan bass pada jari tangan kiri belum semestinya dimainkan dengan baik untuk membangkitkan mood bernyanyi jemaat. Atau lagu dengan irama waltz organis belum bisa memberi nuansa waltz misalnya pada nyanyian KJ. 400 Kudaki Jalan Mulia bisa diberikan sentuhan waltz yang kental agar ada ketegasan pada birama dan irama; 5) Belum jelas permainan notasi marcato dan legato; 6) Untuk nada dasar nyanyian jemaat cenderung tetap dimainkan sesuai partiture; 7) Organis memainkan nyanyian jemaat dengan tempo lambat pada beberapa lagu karena menyesuaikan dengan kebiasaan bernyanyi jemaat; 8) Cara bermain yang masih mengunakan akor pada tangan kiri membuat permainan hanya berupa perpindahan akor semata tanpa kombinasi bass inversion dan lompatan nada yang mengantar pada kombinasi nada berikutnya. Lebih berdasarkan 'feeling' daripada partitur sehingga ada akor-akor yang terlewatkan; 9) Untuk pemilihan tone masih dominan menggunakan tone organ belum ada yang mengkombinasikan dengan string untuk lagu-lagu yang riang; 10) Untuk nyanyian yang jarang atau baru dinyanyikan terdapat kesalahan bermain; 11) Pemandu lagu berusaha menyanyikan nyanyian jemaat sebaik-baiknya dengan memperhatikan tempo jemaat dan organis, tetapi ada juga kecenderungan untuk menyanyi dengan tempo sendiri; 12) Usaha untuk mempertahankan tempo yang ada pada intro lagu dari organis tetap dilakukan sehingga mulai ada kestabilan tempo; 13) 
Lagu pada setiap nyanyian jemaat berusaha dinyanyikan sesuai partitur secara keseluruhan artinya notasi marcato dan legato mulai jelas; 14) Kadang-kadang ada melakukan kesalahan bernyanyi pada beberapa nyanyian yang dianggap jarang atau bahkan baru dinyanyikan karena latihan hanya dilakukan sebelum kebaktian; 15) Bermain band dengan penyajian musik gereja tentu menghadapi berbagai kendala dan ini dianggap sebagai proses pematangan untuk mencapai performa yang maksimal atau punya 'greget'; 16) Masalah utama yang bersifat teknis penyajian adalah penguasaan dan pembawaan nyanyian jemaat itu sendiri; 17) Permainan akor yang berbeda antar personil gitar, bass dan kibod pada beberapa nyanyian membuat penyajian menjadi tidak utuh sehingga menghasilkan bunyi yang tidak harmonis; 18) Untuk tempo, irama dan birama ditentukan oleh permainan drum. Terkadang penguasaan birama yang belum mapan membuat nyanyian dengan birama 3/4 bisa bias menjadi 4/4 atau sebaliknya, juga 6/8 bisa menjadi 3/4 atau sebaliknya; 19) Untuk latihan sudah diatur pada hari Sabtu semua personil diharapkan hadir, karena daftar lagu untuk kebaktian sudah ada di berita jemaat, sehingga penyajian diharapkan lebih maksimal; 20) Untuk pemandu lagu berusaha melakukan penyesuaian dengan kelompok band terutama untuk attack maupun antar bait nyanyian, sehingga kelompok band mengiring pemandu lagu maksudnya kalau nyanyian sudah berjalan ada situasi-situasi yang sifatnya toleransi untuk saling menyesuaikan dan meminimalkan kesalahan; 21) Adanya keragu-raguan dalam bernyanyi dan mengiring untuk nyanyian jemaat yang jarang atau baru dinyanyikan; 22) Sumberdaya yang terbatas baik dari segi kualitas dan kuantitas menyebabkan performa yang tidak maksimal dalam penyajian; 23) Terbatasnya waktu latihan karena kesibukan dan tempat latihan hanya di gereja yang notabene tempat kegiatan jemaat; 24) Belum pernah mengikuti workshop musik gereja; 25) Pandangan jemaat yang masih menganggap penggunaan band kurang cocok untuk GKE; 26) Karakter nyanyian jemaat yang digunakan di GKE hanya cocok untuk iringan organ saja; 27) Terbatasnya referensi bermain yang hanya menggunakan notasi musik angka belum diperkuat dengan basic musik notasi musik balok, sehingga pola bermain akor lebih kental daripada kombinasi seperti komposisi edisi harmoni notasi balok; 28) Mengutamakan pelayanan firman pada saat kebaktian artinya menyanyi hanya sebagai pelengkap saja dan belum ada rasa untuk menyeimbangkan keduanya; 29) Penetua dan diakon belum semuanya memberdayakan diri dalam hal menjadi pemandu lagu membantu atau mengganti pemandu lagu yang berhalangan dan anggapan bahwa bernyanyi tidak semudah yang mereka kira; 30) Masih ada kebiasaan bernyanyi yang tidak sesuai dengan partitur dan tetap diusahakan oleh pemain organ, band dan pemandu lagu untuk mengiring sesuai partitur; 31) Untuk pemain organ permainan masih belum memiliki pengetahuan teori musik yang memadai dan dalam prakteknya masih bermain secara akor dan belum mengacu kepada cara bermain dengan partitur balok; 32) Untuk pemandu lagu dari segi penguasaan nyanyian cukup memadai dan bisa mengambil inisiatif pada saat nyanyian sedang dinyanyikan; 33) Ada pemain organ yang bisa mengemas permainannya dengan baik artinya sesuai dengan rambu-rambu yang ada dalam partitur, tetapi ada juga yang masih belum menyajikan secara maksimal dari segi pengemasan nyanyian; 34) Kendala yang dihadapi organis 
penguasaan nyanyian, tempo, akor dan kolaborasi secara keseluruhan baik dengan pendeta, liturgos, pemandu lagu dan jemaat; 35) Kendala yang dihadapi pemandu lagu penguasaan nyanyian, tempo dan kemampuan menggiring jemaat dalam satu kesatuan bernyanyi yang utuh artinya tidak ada yang lebih dulu atau terlambat.

\section{Rekomendasi untuk Penelitian Lanjutan}

Untuk lebih memantapkan performa musik gereja perlu penelitian lanjutan yang bisa memberi solusi dalam meningkatkan kompetensi bernyanyi dan bermusik bagi semua perangkat musik gereja. Penelitian tersebut dapat menjadi rekomendasi untuk melakukan pengabdian kepada masyarakat bidang musik gereja agar juga bisa lebih meningkatkan intensitas dan kualitas latihan. Kemudian pemusik dan penyanyi bisa bersinerji maksimal pada saat kebaktian Minggu dan bila ada masalah-masalah dalam menguasai lagu-lagu baru jangan ragu dan malu bertanya kepada yang dianggap mampu mengatasi.

Penelitian lanjutan juga bisa melakukan penelitian tentang cara mengembangkan musik gereja dalam bentuk Forum Musik Gereja yang terdiri dari para pendeta, pemandu lagu, organis dan kelompok band, praktisi seni musik dan seni suara untuk mendiskusikan apa yang telah dicapai dan apa yang menjadi permasalahan dalam penataan musik gereja. Penataan secara terus-menerus untuk mendapatkan bentuk penataan yang representatif oleh Majelis Jemaat perlu dilakukan agar semua perangkat musik gereja bisa bersinerji maksimal.

\section{Kesimpulan}

Beberapa kesimpulan penting dapat diambil dari hasil penelitian ini sebagai berikut: 1) Musik gereja di Gereja Sinta Kuala Kapuas telah berkembang cukup baik secara penataan dan diatur sedemikian rupa dalam bentuk penjadwalan pada berita jemaat Minggu dan dilaksanakan oleh organis serta pemandu lagu; 2) Dalam penyajiannya perangkat musik gereja berusaha menyajikan musik gereja melalui mengiring nyanyian jemaat sebaik mungkin sesuai dengan ketrampilan bermain dan bernyanyi atau dengan latar belakang pengetahuan musik dan seni suara yang ada. Dengan segala keterbatasan pengetahuan perangkat musik gereja ini mengabdi dan meluangkan waktunya untuk mengendalikan nyanyian yang telah dipilih dan dinyanyikan; 3) Dalam perkembangannya organis, pemandu lagu, band juga melakukan pertemuan dan konsultasi dengan pendeta pelayanan kebaktian Minggu untuk masalah nyanyian jemaat yang akan dinyanyikan dan kalau perlu ada latihan singkat untuk nyanyian yang baru atau jarang dinyanyikan. Latihan singkat juga ada yang dilakukan sebelum kebaktian dengan beberapa jemaat yang telah hadir lebih awal; 4) Dari segi fasilitas peralatan musik dan sound system yang disediakan oleh Majelis Jemaat sudah memadai. Di gereja Sinta terdapat seperangkat alat band dan sound system yang sudah dipakai dan terpelihara dengan baik; 5) Pada saat kebaktian terdapat laptop dan LCD untuk penayangan liturgi dan nyanyian yang dinyanyikan. Ini dilakukan untuk menutupi kekurangan liturgi dan buku lagu yang tidak dimiliki jemaat; 6) Memberdayakan penatua dan diakon yang bertugas pada kebaktian 
Minggu untuk membantu pemandu lagu mengiring jemaat. Hal ini penting dilakukan untuk mengantisipasi apabila pemandu lagu berhalangan dalam melaksanakan tugas dan penatua, diakon yang bertugas bisa mengganti pemandu lagu; 7) Permasalahan utama adalah kuantitas perangkat music gereja yang terbatas dan kualitas bermain dan bernyanyi tidak ditunjang dengan teori musik dan seni suara yang mapan artinya mereka hanya menguasai nyanyian hanya secara otodidak dan pengalaman. Pengakoran lagu juga masih ada yang belum sesuai dengan alur lagu dan dalam kelompok band sering terjadi tidak sinkron antar pemain dalam hal akor; 8) Kendala yang dihadapi organis penguasaan nyanyian, tempo, akor dan kolaborasi secara keseluruhan baik dengan pendeta, liturgos, pemandu lagu dan jemaat. Hal ini berimbas terhadap performa menyanyi jemaat yang terkadang tidak sesuai partitur; 9) Dari segi insentif sudah ada diberikan oleh pihak Majelis Jemaat kepada perangkat musik gereja.

\section{Daftar Pustaka}

Abineno, J. L. CH. (1986). Gereja dan Ibadah Gereja. BPK Gunung Mulia.

Ambarwati, Dwi Retno Sri. Tinjauan Akustik Perancangan Interior Gedung Pertunjukan. Imaji 104, Vol. 7, No. 1, Februari 2009 : 88 - 104.

Banoe, Pono. (2003). Kamus Musik. Kanikus.

Jamalus. (1988). Panduan Pengajaran Buku Pengajaran Musik Melalui Pengalaman Musik. Jakarta: Proyek Pengembangan Lembaga Pendidikan

Muhammad, Farouk dan Djaali, H. (2005). Metodologi Penelitian Sosial (edisi revisi). Jakarta: PTIK Press, Restu Agung Jakarta.

Pahan, Berth P. (2020). Pengantar Pelayanan Musik Gereja. IAKN Palangka Raya.

Soumokil, Godlief. (2001). Musik Gereja. Yamuger-GKE.

Soeharto, M. (1992). Kamus Musik. Gramedia Widia Sarana Indonesia

Ukur, Fridolin. (2001). Syair Dalam Nyanyian Gereja (Menulis Lirik/Syair Lagu). Yamuger-

GKE. 